\title{
Toplumsal Cinsiyet \\ Hiyerarşisinin Sonucu Olarak \\ Matmazel Julie Oyununda Ressentiment (Hınç) İzleri
}

Geliş Tarihi/Received: 01.02 .2021

Kabul Tarihi/Accepted: 07.09.2021

DOI: 10.46372 /arts.907692

\author{
Berkay ERDOĞAN \\ Dokuz Eylül Üniversitesi Güzel Sanatlar Enstitüsü \\ Sahne Sanatları Ana Sanat Dalı Yüksek Lisans Programı \\ berkayerdogan93@gmail.com \\ ORCID: 0000-0003-0121-5508
}

\begin{abstract}
Öz
Bu çalışma, on dokuzuncu yüzyılla birlikte yeniden kurgulanan toplumsal cinsiyet rollerinin oluşturduğu iktidarı ve bu iktidarın ressentiment (hıç) ile ilişkisini August Strinberg'in Matmazel Julie oyunu üzerinden tartışmaktadır. Dönemin önemli bilimsel buluşları olan pozitivizm, Evrim Teorisi ve Sosyal Darwinzm'in toplum açıklamasındaki iktidar ilişkisinin oyun ile olan bağlantısı üzerinde durulmuş, toplumsal cinsiyet rolleri bağlamındaressentimentoluşumu anlaşılmayaçalışılmıştır. Bubağlamda ressentiment oluşumu Hegel'in efendi-köle diyalektiği, Nietzsche'nin efendi-köle ahlakı ile Beauvoir'ın toplumsal cinsiyet yaklaşımı temel alınarak incelenmiştir. Toplumsal cinsiyet ve iktidar ilişkisinin sonucu olarak ressentimentı oluşturan intikam ve haset kavramlarına bakılmıştır. Oyunda Kont'un üst otoriteyi, Kristin'in toplumsal bakışı temsil etmesi ile ressentimentı oluşturan araçlar olduğu sonucuna varıımıştır. Beauvoir'ın aşkın ve içkin kavramları, toplumsal sınıfların çatışması ve efendi-köle ilişkisi hem Jean ile Julie'nin kendi arasında hem de Kont ile ilişkilerinde saptanmıştır. Hegel'in efendi-köle diyalektiğinin ressentimentı oluşturan temel faktör olduğu, Nietzsche'nin efendi-köle ahlakının aynı bedende olabileceği görüşünden hareketle oyunda birbirleri üzerinde kurmak istedikleri iktidar bağlamında ressentimentın hem Julie hem de Jean için tek bedende bulunduğu sonucuna varımışıır.
\end{abstract}

Anahtar Kelimeler: toplumsal cinsiyet, iktidar, efendi-köle, ressentiment, matmazel julie

Erdoğan, B. (2021). Matmazel Julie Oyununda Ressentiment (Hınç) İzleri.

ARTS: Artuklu Sanat ve Beşeri Bilimler Dergisi, 6, 133-158. 


\title{
Traces of Ressentiment in The Play Miss Julie as a Result of Gender Hierarchy
}

\begin{abstract}
This study discusses the power created by the gender roles reconstructed in the nineteenth century and the relationship of this power with ressentiment through August Strinberg's play Mademoiselle Julie. The connection between the power relationship of positivism, the theory of evolution and social Darwinism, which are important scientific discoveries of the period, with play is emphasized, and the formation of ressentiment has been tried to be understood in the context of gender roles. In this context, the formation of the ressentiment has been examined on the basis of Hegel's Master-Slave Dialectic, Nietzsche's Master-Slave Ethics and Beauvoir's gender approach. The concepts of revenge and envy that constitute the ressentiment as a result of the relationship between gender and power have been examined. In the play, it was concluded that the Count represents the upper authority, Kristin's representation of the social perspective, and are the means that form the ressentiment. The concepts of the transcendent and immanent of Beauvoir, the conflict of social classes and the masterslave relationship have been determined both between Jean and Julie and their relations with the Count. Based on the view that Hegel is the main factor that constitutes the master-slave dialectic painter, Nietzsche's view that the master-slave morality can be in the same body, it has been concluded that the painter is in one body for both Julie and Jean in the context of the power they want to establish on each other in the play.
\end{abstract}

Keywords: gender, power, master-slave, ressentiment, miss julie 


\section{arts}

\section{Gíriş}

On dokuzuncu yüzyıl toplumsal değişimlerin fazlaca yaşandığı bir dönemdir. Modernleşme, Sanayi Devrimi gibi gelişmelerin yaşandığı bu dönemde bilimsel gelişmeler de hız kazanmışıı. Döneme damgasını vuran ve sosyal alanda da büyük etkisi olan düşünce ise Darwin'in Evrim Teorisidir. Darwin, Türlerin Kökeni (1859/1976) eserinde kalıtım (soyaçekim), türlerin çatışması, doğal seçilim gibi olgularla açıkladığı Evrim Teorisi'nde insanı mercek altına alır. Darwin, Evrim Teorisi ile çevre koşullarının insanı şekillendirdiğinden ve değişen çevre koşullarııın canlıların özelliklerinin gelişiminde önemli rol oynadığından bahseder. Bu bağlamda canlıların hayatta kalabilmek için mücadele etmesi gerekmektedir ve Darwin, doğal seçilim ile doğada uyum sağlayabilen canlıarın hayatta kalabileceğini söyleyerek Evrim Teorisi'nin temel argümanlarını oluşturur. Evrim Teorisi etkisiyle şekillendirdiği kuramında Herbert Spencer ise toplumu Evrim Teorisi ile okur. Spencer toplumu bir organizmaya benzetir ve toplumun da organizma gibi büyüdüğünü, büyüdükçe de homojen yapıdan heterojen yapıya evrildiğini ifade eder. Dolayısılla heterojen toplum yapısı farkllıklarından dolayı uzlaşım içinde yaşar ve bir bütünü meydana getirir (Kongar, 2013, s. 92). Bununla birlikte toplumun çevreyle olan ilişkisine dikkat çeker. Sosyal Darwinizm olarak adlandırılan bu yaklaşıma göre toplumsal gelişme, doğada olduğu gibi toplumda da güçlü olanın, çevreye adapte olabilenin gelişmesi gerektiği ilkesine dayanır (Edinsel, 2014, s. 92).

Evrim Teorisine paralel olarak on dokuzuncu yüzyllda toplumsal cinsiyete ilişkin olarak da Viktorya Dönemi Ahlak Yasaları'nın önemli etkisi görülmektedir. Sanayi Devrimi ve modernleşmeyle birlikte kamusal alan ve özel alan ayrımının yaşanması ile burjuva ahlakının ortaya çıkması cinsiyetin biyolojik indirgemeciliğine, dolayısıyla toplumsal cinsiyet rollerinin yeniden düzenlenmesine sebep olmuştur (Sancar, 2014, s. 23). Viktorya Dönemi'nin kadını özel alana sıkıştıran ve biyolojik indirgemecilik ile kadının güçsüz, ikincil olduğunu varsaydığı ahlak yasalarr; kadının konumunu annelik üzerinden var eder. Kadın erkekten "farkı olarak" erkeğin boyunduruğu altındadır. Viktorya Dönemi Ahlak Yasaları ile kadına yüklenen annelik, cinselliğini bastırma, iffetli olma gibi kadını sınırlandıııcı bakış açııı toplumsal cinsiyete dayalı eril tahakkümün sonucu olarak kadınların ikincilleştirilmesiyle; erkeklerin ise hegemonik erkeklik altında ezilmeleriyle sonuçlanmışır. Evrim Teorisi'nin, Viktorya Dönemi'nin ahlaki normlarının güçlendiği sırada ortaya çıkması dönemin ahlak anlayışı konusunda da tartışmalara yol açmışır. 
Dönemin egemen kültürü, kadınların ve vahşilerin paylaştıkları ileri sürülen aşağı, ilkel doğayı ima eden ceşitli imgeler üretti; sözümona "cinsel bilim" (seksoloji) ise bu kültüre "sağlam bir zemin" sağladı. Bu ortak çabanın üzerinde uzlaş̧ığı konu, kadınların anatomik, fızyolojik, psikolojik ve zihinsel olarak erkeklerden içkin biçimde farklı olduklarıydı. Türün evrimi sırasında kadınlar, tıpkı "ilkel halklar"ın Avrupalılar'dan geri kalması gibi, erkeklerden geri kalmışlardı (Berktay, 2015, s. 136).

Sosyal Darwinizm'in toplumda güçlü olanın hayatta kalacağı ve otorite sahibi olacağı görüşü toplumsal cinsiyet bağlamında da biyolojik indirgemecilikle erkeğin güçlü olduğu ve otorite sahibi olması gerektiği görüşünü meydana getirir. Bu bağlamda Sosyal Darwinizm ile toplumsal cinsiyete dayalı güç ilişkisinin yarattığı tahakküm; haset, korku, intikam ateşi gibi duyguların oluşumuyla ressentimente (hınç) dönüşmeye yatkın hale gelir.

Fransızca kökenli bir sözcük olan ressentiment Fransızcada "saygısızığın, küçük düşmenin hatırasıyla öç alma isteği" anlamına gelmektedir ("Ressentiment", 1954). Scheler (1912/2015, s. 20) ressentimentın anlamını en iyi karşılayan sözcüğün Almancadakigroll (hınç, kin) sözcüğü olduğunu belirtir. Hınç, egonunegemenliğinden bağımsız bastııımış bir gazap duygusuyken; ressentiment düşmanca duyguların tekrar tekrar yaşanılarak şekillenmesini ifade eder. Tek başına düşmanca niyet taşımamasına karşın ressentiment, bu tür duyguları beslemektedir. Ancak yine de sözcüğün tam karşılığını yansıtmaması ve Nietzsche'nin özellikle Ahlakın Soykütüğü kitabında sözcüğü felsefi bir terim olarak kullanmasından kaynaklı Scheler de ressentiment sözcüğünü kullandığını belirtmektedir. ${ }^{1}$

Natüralist-realist yazın "somut yaşam gerçeğinin yansıtılması, çevre etmenlerinin dikkate alınması, bilim yönteminin uygulanması, düşüncenin dış dünyaya açılması, ilüzyon (yanılsama) yaratılması" (Şener, 2017, s. 174) noktasında toplumsal ve bilimsel gelişmelerden etkilenmiştir. Natüralizmin tiyatrodaki önemli temsilcilerinden A. Strindberg tarafından kaleme alınan Matmazel Julie oyunu, soylu bir genç kadın olan Matmazel Julie ile uşağı Jean arasındaki aşk ilişkisi üzerinden dönemin toplumsal yapısına ve bu yapının çözülmesine dair bir perspektif sunar. Jean, Kristin ile nişanlı olmasına rağmen sınıf atlayıp kent soylu birine dönüşebilmek için Matmazel Julie'yi, Matmazel Julie ise özgür bir kadına dönüşebilmek için Jean'ı araç olarak kullanır. Evin hizmetçisi Kristin, sınıfını kabullenmiş geleneksel bir kadınken oyun boyunca varlığını hissettiren ancak görünmeyen Kont ise üst otoriteyi temsil eder. Bu bağlamda oyun iktidar ilişkilerini Sosyal Darwinist bir noktadan ele alırken

1 Bu sebeple çalışma boyunca ressentiment kavramı Scheler'in ele aldığı şekilde, orijinal ismiyle kullanılmışır. 


\section{arts}

çevre ve kalıtımın insan üzerindeki etkisine Matmazel Julie ile annesi arasındaki ilişkiyle ışık tutmaya çalışır.

Güç ilişkisinden kaynaklı ressentiment kavramının oluşumunun anlaşılmaya çalışılacağı bu çalışmanın amacı, toplumsal cinsiyet rollerinin oluşumunda ressentiment kavramının ve deneyiminin rolünüveressentiment kavramının Matmazel Julie oyunu üzerindeki yansımalarını tespit etmektir. Toplumsal cinsiyet rollerinin ressentiment kavramıyla olan ilişkisi temelde Beauvoir'ın toplumsal cinsiyet yaklaşımı ile Hegel ve Nietzcehe' nin efendi-köle ilişkisi çerçevesinde ele alınacaktır. Hegel ve Nietzscehe'nin köle-efendi ilişkisi Beauvoir'ın toplumsal cinsiyet yaklaşımında kadın ve erkek rollerinin köle ve efendi konumunda ele alınmasına olanak tanır. Bu bağlamda çalışmanın önemi feminist bakış açısıyla kadın ve erkeğin toplumsal cinsiyet normları çerçevesinde ressentiment duygusunu yaşama sürecinin ne ölçüde farklılaştığını daha önce toplumsal cinsiyet literatürüyle ilişki kurulmamış bir oyunu ön plana çıkararak ele alması ve bu eşitsizliğin toplumsal alanda nasıl işlediğine dair örnek göstermeyi hedeflemesidir. Bu bağlamda önce toplumsal cinsiyet, iktidar ve ressentiment ilişkisine bakılacak daha sonra bu kuramsal çerçeve ışığında oyunla ilişki kurulacaktır.

\section{Toplumsal Cinsiyet, İktidar ve Ressentiment ilişkisi}

Toplumsal cinsiyet en basit tanımıyla biyolojik cinsiyetin toplumsal ve kültürel normlarla inşa edilişidir. Bu açıdan, cinsiyete atfedilen roller bağlamında kadınlık ve erkeklik bir kurgusallığa yaklaşırken aynı zamanda eşitsizliği de beraberinde getirmektedir. Bu eşitsizlik verili bir olgu olarak karşımıza çıkmaktadır. Kadın ve erkek için bir yandan zorunluluğa dönüşen eşitsizlik, öte yandan kendini görev bilinci olarak da göstermektedir. Örneğin ev işlerini üstlenme, çocuk doğurma gibi görevler kadına yüklenirken; erkekten ise çalışması ve iktidarlı olması beklenmektedir. Bu normlar, toplumun bütün kurumlarında kendini göstermekle birlikte özellikle aile kurumunda yeniden üretilmektedir.

Bu bağlamda Beauvoir'ın ünlü sözü "Kadın doğulmaz: Kadın olunur" (1949/2019, s. 13) toplumsal cinsiyete dair önemli bir yaklaşımı ortaya koymaktadır. Varoluşçu bir feminist olan Beauvoir Ikinci Cinsiyet (1949/2019) eserinde varoluşçu felsefenin ben-öteki düalizmini ve özgürlük² kavramını toplumsal cinsiyet ilişkisi içinde 2 Varoluş̧̧ulukta ben ve öteki düalizmi, bireyin kendini var ederken öteki ile kurduğu ilişkiyi mesele edinir. Ontolojik olarak birey var olabilmek için özgür seçimler yapabilmelidir. Ancak öteki, bu özgürlük önünde engel teşkil eder. Bireyin kendini gerçekleştirebilmesi için özgür seçimlerini ötekinin değil, kendi değerleri bağlamında inşa edebilmesi gerekmektedir. 
inceleyerek, erkek egemen bir toplumda cinsiyetin de erkek egemen bir bakış açısıyla yaratıldığını ifade etmektedir. Toplumsal cinsiyet bağlamında kadının varlık olabilmesi için özgür seçimler yapabilmesine engel olan kadının öteki konumuna iten erkektir. Kadın-erkek diyalektiği içinde biyolojik farklılık üzerinden oluşturulan baskı sonucu kadın " 'ana' ve sadık 'eş' olarak, kendi başına ve kendisi için bir varlık olarak değil, erkek için bir varlık olarak kurgulanır" (Berktay, 2015, s. 157). Beauvoir, kadının toplumsal yapının her alanında baskılandığını, anne ve eş rolüne hapsedildiğini, özgürlükten mahrum bırakıldığını, tarih sahnesinde görmezden gelindiğini belirterek bu durumun bilimin (antropoloji, psikanaliz, biyoloji gibi) ataerkil egemenliğiyle temellendirildiğini açımlar.

Bunu açıklarken Sartre'ın "kendinde varlık" (être-en-soi) ve "kendi için varlık" (être-pour-soi) kavramlarından yararlanır. Sartre (2011) Varlık ve Hiçlik eserinde kendinde varlığı, özün varoluştan önce geldiği durumu açıklamak için kullanır. Kendinde varlık değişmezdir, özlerinin sınırları içinde varlığını sürdürür. Kendi için varlığı ise özgür seçimlerle varlığını oluşturan insanı tanımlamak için kullanır. Beauvoir, kadınların kültürel olarak kendinde varlık içine sıkıştııılığını ve özlerini oluşturamadığını söylemektedir. Zira Beuavoir'a göre kadın içkindir. Aşkınlık ve içkinlik³ kavramlarını toplumsal cinsiyetle okuyan Beuavoir, aşkınlığın özgürlükle eşdeğer olduğunu ve sıkıştırılamayan, devinim halinde olan yaratıcı gücü ifade ettiğini söylemektedir. Bunun karşısında konumlanan içkinlik ise edilgenliği, yalnızca zorunlu gereksinimlerin karşılanabildiği bir alanı ve döngüsel bir zamanı ifade etmektedir. Beauvoir, erkek egemen düzende özgürlüğe sahip erkeklerin aşkın, kadına yüklenen toplumsal roller içerisinde kadının özerk özgürlüğünün içkin olduğunu söylemektedir (Beauvoir, 1949/2019, s. 13-14).

Kadının varlığı, erkeğin varlığı tarafından konumlandırılmaktadır. "Kadın kendini erkeğe göre belirler ve farkılış̧ııır, erkek kadına göre değil; kadın, özsel olan karşısında özsel olmayandır. Erkek Özne'dir, Mutlak olandır, Kadın Başka'dır" (Beauvoir, 1949/2019, s. 26). Cinsiyete dayalı iş bölümü başta olmak üzere toplumsal alanlarda kendini var edebileceği her türlü araçtan yoksun bırakılmıştır. "Böylece kadın kendini özne olarak talep etmez, çünkü bunun için gerekli somut araçlardan yoksundur, çünkü onu erkeğe bağlayan zorunlu bağın karşıığını ortaya koymaksızın

3 "içkinlik kadının doğa ve yaşamla ilişkili olduğu, sürekli tekrar eden doğurganlığını da içeren rutin bir var oluş şeklidir. (...) Bir de insana dair aşkınlık boyutu vardır. Bu boyutta insan eylemseldir ve yaşadığı dünyayı değiştirerek, dönüştürerek ve üreterek bu dünyada iz bırakır." (Aydınalp, 2020, s. 474) 


\section{arts}

bu bağı hisseder ve çünkü çoğu kez 'Başka' rolünden hoşlanır”' (Beauvoir, 1949/2019, s. 30).

Bu yaklaşımı ile Beauvoir, Hegel'in köle-efendi diyalektiğinden yola çıkarak kadın-erkek arasındaki ezen-ezilen ilişkisini ortaya koyar. "Kadınlar Hegel'in efendi/ köle diyalektiğinde olduğu gibi kölenin efendi tarafından tanınması adına mücadele etmezler, bu mücadele kadın/ erkek söz konusu olduğunda daha çok erkekler arası bir mücadeleden ibarettir" (Aydınalp, 2020, s. 478). Bu bağlamda toplumsal cinsiyet, güç ilişkisinin ortaya çıktığı bir iktidar ilişkisini de meydana getirir. Zira iktidar, güç ilişkilerinin konumlanması olarak da tanımlanabilir. Foucault'ya göre "iktidar bir ilişki, bir eylem biçimidir" (Foucault, 2016, s. 20). Foucault, iktidarın makro ve mikro ölçekte, her yerde olduğunu söyleyerek geniş bir tanımlama sunar.

İktidarın önemli alanlarından olan toplumsal cinsiyet de kendini hegemonik erkeklik üzerinden hem kadınlar için hem de erkekler için var eder ve tahakküm oluşturur. Connell (2016, s. 269): "Dinsel öğreti veya pratiğe, kitle iletişim içeriğine, ücret yapılarına, ev tasarımına, yardım/vergilendirme politikalarına gibi olgulara kök salan üstünlüğün hegemonya" olduğunu, bununla birlikte üstünlüğün ötekinin ikincilleştirmesi üzerine kurulu olduğunu söyler. Yani Connell, hegemonik erkekliği, erkeklerin hâkimiyetini, kadınların ise bağlı̆ğını garanti altına alan ataerkilliğin meşruiyet problemine cevap veren bir toplumsal cinsiyet pratiği olarak tanımlar. Ancak hegemonik erkeklik yalnızca kadınlar üzerinde kurulan tahakkümü ifade etmez. Aynı zamanda erkekler için de kurulu bir üst erkeklik modelini kapsar. Connell (2016, s. 269) bu hegemonik formun illa erkekliğin en yaygın olanını temsil etmesi gerekmediğini, çoğu erkeğin var olan hegemonik erkekliğe ulaşmak veya uyum sağlamak için çabaladığını söyler. Sosyal Darwinist bir noktadan ele aldığımızda hegemonik erkekliğin, içinde sınıfsal bir yapı oluşturduğunu söyleyebiliriz. Bu yapı içinde erkekler de bu iktidar hiyerarşisinde yer edinebilmek için mücadele etmektedirler.

Bu doğrultuda iktidarın yarattığı tahakküm ve buna bağlı olarak da eşitsizlik ressentiment kavramını açığa çıkarır. Scheler (1912/2015, s. 24) ressentiment kavramının haset, intikam arzusu, nefret, kötüleme gibi belli duyguların bileşiminden oluştuğunu söylemektedir. Bu bağlamda cinsiyet hegemonyasının oluşturduğu güç ve tahakküm ilişkisi Hegel'in köle-efendi diyalektiğine ve Nietzcheci'nin köle-efendi ahlakına benzer bir çerçevededir ve bunlar ressentimentın oluşumunda önemli anahtar kavramlardır. 
Hegel'e göre insan bir öz-bilinçtir ve öz-bilincin oluşumu da istençten geçer. Bu istenç, tanınma, başkası tarafından kabul görme, kendini kabul ettirme istencidir. Bu istenç kişiyi eyleme götürür. Bunun için iki veya daha çok isteyen benin varlığı, buna bağlı olarak da bu benlerin savaşı söz konusudur. Tanınma için gereken başat ilke hayatta kalmaktır. Hegel'in köle-efendi diyalektiği bu savaşın sonucudur (Bumin, 1987, s. 26-31). Köle-efendi diyalektiği içinde insan saygınlık kazanmak, kabul görmek, öz-bilincinin varlığını sağlamak için girdiği savaşta hayatını tehlikeye atmalıdır. Ancak hayatının sonlanmaması için tutumunu değiştirmek ve diğerinin özbilincini kabul etmek durumunda kalır. Bu savaşın sonunda savaşı kazanan efendi, ötekinin hayatını bağışlamalı ve özerkliğini yok ederek onu köleleştirmelidir. Köle, kendi doğasını aşamadığı için efendisininkini kabul etmek durumunda kalacaktır. Efendinin hizmetine giren köle, korku (ölüm korkusu) ve çalışma (korku kaynaklı bir çalışma) güdüleriyle efendisine hizmet edecektir (Bumin, 1987, s. 32-36).

Toplumsal cinsiyetin oluşturduğu ataerkil normlar erkeğin efendi, kadının köle olduğu bir anlayış oluşturması bakımından önemlidir. Plumwood (2017) Feminizm ve Doğaya Hükmetmek kitabında kadının doğa, erkeğin akıl ve kültür ile özdeşleştirildiğini, dolayısıyla aklın efendi kimliğine bürünerek doğayı egemenlik altına almaya çalıştığını söylemektedir. Bu durumda akılla özdeş olan efendi erkek de doğa ile özdeş olan kadını köleleştirmektedir. Aynı zamanda Beauvoir'ın da ifade ettiği gibi "başka" olmak kadını bu iktidar yapısının içine çekerken kadının aynı zamanda var olabileceği araçlardan yoksun bırakılarak içkin bir varlığa dönüştüğünü dolayısıyla köle konumunda olmaktan da hoşlandığını söylemektedir (Beauvoir, 1949/2019, s. 30). Buradan hareketle Nietzsche, köle-efendi ahlakında köle-efendi ilişkisini toplumsal alanda yalnızca statüyle ve/veya ayrıcalıkla özdeştirmez. Efendi ve köle ahlakının anlaşılmasında tahakküm ilişkisi önemli olmasına karşın, bu ilişki Nietzsche'ye göre efendi-köle ahlakının anlaşımasında yeterli değildir. Aynı kişide hem köle hem de efendi ahlakı bulunabilir. Soylu ahlak kendini kabul edip severken köle ahlakında ulaşılamamanın verdiği bir hınç duygusu vardır. Köle ahlakına yön veren de bu hınç duygusudur. Hınç duygusu kendisini var edemeyen, intikam arzusuyla dolu ve kendini hayali bir intikamla avutan kölenin duygusudur (Nietzsche, $1887 / 2000$, s. 20-42).

Ressentimentı anlamak için Hegelyen ve Nietzscheci görüş yanında ressentimentı oluşturan önemli diğer unsurlara, hasete ve intikam arzusuna da 


\section{arts}

bakmamı gerekmektedir. Intikam arzusu, bir incinme veya saldırı barındırır. İntikamın iki temel özelliği vardır. İlki iktidarsızlık hissidir. İkinci olarak ise iktidarsızlıktan doğan kısasa kısas bilincidir. İntikam arzusu aynı zamanda bir tür bastırma eğilimi de getirir. Ressentiment, saklı kalmış güçlü beklentiler veya toplumsal konumu yetersiz ancak buna rağmen büyük bir kibir duyan insanın duygusudur. Dolayısıyla intikam, her zaman zayıf olanın tavrıdır (Scheler, 1912/2015, s. 24-31). İntikam, adalet için duyulan bir tutkudur. Kişinin kendi nedenlerine bağlı olarak kendini haklı görmesinden kaynaklanan durum öç alma, acısını çıkarma ve adaleti sağlama gibi öğelerin bir birleşimi olarak açığa çıkar (Soloman, 2016, s. 180-181). İntikam duygusu, kişinin kontrolü dışında gelişen kalıcı bir duygudur ve incinme gibi durumların uzantısı olarak ressentimenta dönüşmeye meyillidir. O halde toplumsal eşitliğin sağlanmadığı; servet dağılımının, iktidarın ve kültürel sermayenin derin farklılıklar yarattığı toplumlar ressentiment için uygun zemini oluşturur. Buna en iyi örnek proleteryanın yaşadığı varoluşsal intikam inancıdır (Scheler, 1912/2015, s. 32-33).

Ressentimentagötüren diğerkavramlardan hasetbizimsahip olamayacağımı herhangi bir "şey"in 4 bir başkası tarafından sahipliği durumunda yaşanılan iktidarsızlık hissinden kaynaklanır. Arzu duyulan "şey"e ulaşılamamasından kaynaklanan yoksunluk, o "şey"in sahibini yoksunluğumuzun sebebi olarak görmemizle alakalı hasedi doğurur (Scheler, 1912/2015, s. 25). Hasedin hedefi bir kişi olabileceği gibi bir kişinin sahip olduğu her şey ile ilgili de olabilir. Değiştiremeyeceğimiz yetenek, beceri, statü gibi unsurlar hasedin olmazsa olmaz sebepleridir (Soloman, 2016, s. 166). Scheler'e göre (1912/2015, s. , 36): "Imrenilen değerler bu haliyle elde edilemez olduğu ve üstelik kendimizi başkalarıyla kıyaslamayacağımı bir alanda yer aldığı zaman, haset ressentimenta yol açar". Bu doğrultuda ötekinin varoluşuna duyulan muhaliflik; baskı, kınanma ve aşağılanma olarak hissedilir. Scheler buna varoluşsal haset demektedir ve bunu ressentimentın en güçlü kaynağı olarak ifade eder (1912/2015, s. , 36).

Hegel'in efendi-köle diyalektiği, Nietzsche'nin efendi-köle ahlakı gibi ressentiment da toplumsal cinsiyet hiyerarşisini açıklamakta bir anahtar olarak kullanılabilir. Ressentimentı oluşturan yan duygular toplumsal normların bir sonucu olarak erkek egemen bir iktidarın uzantısı şeklinde de karşımıza çıkar. Tahakkümün varlığı, kişinin verili değerlerle olan önlenemez ilişkisi ile karşı konulamaz konumu neticesinde yaşadığı baskı ressentimenta neden olmaktadır. Bu bağlamda 4 Bu "şey" iktidar gibi soyut bir kavram olabileceği gibi, bir nesne de olabilir. 
ressentiment ile toplumsal cinsiyet arasındaki ilişkinin ortaya konulması önem taşımaktadır.

Sanayi Devrimi ile birlikte özel alan-kamusal alanın ayrımı, Viktoryen Ahlak Yasaları ile kadınlık kurgusunun yeniden oluşturulması, kadının özel alana mahkûm edilmesi gibi sonuçlar Scheler'in "dişil ressentiment" kavramını açığa çıkarır. Dişil ressentiment kadının toplumsal normlarla dayatılan edilgenliğiyle alakalıdır. Kadının aşk ve namus arasında yaşadığı ikilem onun ressentiment oluşumundaki en önemli faktörlerdendir (Scheler, 1912/2015, s. 49-50). İktidarın yarattığı toplumsal cinsiyete dayalı tahakküm bilimin egemenliği altında yasalaşırken kadın, Beauvoir'un tabir ettiği biçimiyle kendinde varlık olmaktan kendisi için varlık olmaya geçemez. Güç dengesinin Hegelyen anlamda köle-efendi diyalektiği şeklinde kendini göstermesi ve baskılaması, Nietzscheci anlamda bir ahlak felsefesine bürünmesi ve aşılamaz olduğu düşüncesi kendini gösterir. Bu durumda kadına yüklenen toplumsal rollerle -Beauvoir'ın kavramsallaştırmasıyla- özerk bir özgürlükle içkinliğe mahkûm edilmesi genelde ressentimentı, özelde ise kadınlar için dişil ressentimentı meydana getirmektedir. Erkekler için ise bulundukları sınıf, hegemonik erkekliğin yarattığı tahakküm ile erkeği sınırlandıran bir içkinliğe neden olur. Bu içkinlik erkeğin kendini aşkın konuma getirecekiktidar araçlarını elinde tutamaması nedeniyle ressentimenta dönüşür. Bu doğrultuda bir sonraki bölümde oyundaki toplumsal cinsiyet, iktidar ve ressentiment ilişkisi irdelenecek ve hem Matmazel Julie için hem de Jean için ressentiment oluşumu ayrı başlıklarda incelenecektir.

\section{Matmazel Julie Oyununda Ressentiment}

İskandinav yazar August Strindberg tarafından kaleme alınan Matmazel Julie'nin yazımı 1888'de dönemin toplumsal hareketlerinin yoğun olduğu yıllara tekabül eder. Oyun, kadınların oy haklarını elde edebilmek için başlattıkları Süfrajet Hareketi'nin güçlü olduğu ve Sanayi Devrimi ile birlikte tartışılmaya başlanan işçiaristokrat-burjuvazi sınıflarının çelişkilerinin tartışıldığı yıllarda yazıımıştır.

İki perdeden oluşan oyun, bir Kont'un mutfağında Kont'un kızı Julie, uşakları Jean ve hizmetçileri Kristin arasında geçer. Bir yaz dönümü gecesi ile sabahı arasında Kont'un evde olmadığı zaman diliminde bu üç oyun kişisinin ilişkilerine tanık oluruz. Oyunda Kont -hiç görünmemesine rağmen- zil, eldiven, çizme gibi göstergeler kullanarak varlığını hep hissettirerek üst otoriteyi temsil eder. Bu temsil oyundaki güç ilişkisine dair önemli bir konumlanma yaratmaktadır. Kristin ise sınıfını kabullenmiş ve 
buna sıkı sıkıya bağlı kölenin ahlakını temsil etmektedir. Görünürde Julie ile Jean'ın aşkının anlatııdığı oyun aslında; (Jean) sınıf atlamak ve (Julie) özgürleşebilmek için birbirlerine "muhtaç" iki insanın hikayesidir. Bu iki oyun kişisi arasında yaşanan savaşın kazananı yoktur. Sonunda istediği konuma ulaşamayan Jean, Julie'yi intihara sürükler. Bu bağlamda oyun "tahrip edici tutkuları toplumsal sınıfar arasında vuku bulan bir mücadeleyle bağlantılı olarak ele alı" (Williams, 2018, s. 167).

Natüralizm etkisinde yazılmış Matmazel Julie oyunu insan-doğa ilişkisinin bir uzantısı olarak görülebilir. Natüralizmin insanı doğanın bir parçası olarak ele alıp deney ve gözleme dayalı açıklamada bulunmaya çalışması, Darwin'in kalıtımla gelen özellikler olduğu düşüncesiyle birlikte çevrenin insan üzerindeki etkisi ve yazgısı, yani temelde iç ve dış koşulların neden sonuç ilişkisine odaklanmaları (Şener, 2017, s. 176-181) Matmazel Julie oyununun olay örgüsünün çıkış noktasını oluşturur. Oyun, eril ideolojinin norm ve yaptırımlarının kadınlar üzerindeki tahakkümünü dönemin ana akım düşünce anlayışı ile yansıtmaktadır. Dönemin egemen kültürü kadınların ilkel doğayla bağlantısına vurgu yaparak mitler üretmektedir. Seksolojinin egemen kültüre sağladığı zemin ile kadınların evrim sürecinde erkeklerden geri kaldığı konusunda ortaklaşmaları bu tahakkümü meşru hale getirir (Berktay, 2015, s. 136).

Doğa yasalarının belirleyiciliğinin oyunun pek çok yerinde oyun kişilerinin kararlarını yönlendirmesinde etkili olduğu görülmektedir. Yazarın natüralizm etkisini yansıttığı en önemli göstergelerden biri ise Matmazel Julie'nin annesinin Kont'un otoritesini reddetmesidir. Zira Matmazel Julie'nin erkeklere olan bakış açısını şekillendiren fenomenin çevre ve kalıım bağlamında annesi olduğuna işaret edilmektedir. Diğer taraftan bu durum toplumsal çözülmenin bir uzantısı olarak Kont'un toplumsal konumunun da etkilenmesiyle sonuçlanır. Oyundaki önemli bir diğer gösterge ise kafeste tıkılıp kalmış olmasıyla Julie'nin temsiliyeti olarak görülebilecek kuştur.

Oyunun arzuların açığa çıktığı, doğanın dönüştüğü yaz gündönümü gecesinin yaşandığı süreci kapsaması da çevrenin bu ilişki üzerindeki etkisini göstermesi açısından önemlidir. Bu bağlamda oyunu "cinselliğin heyecanı, ölümün dansı" (Williams, 2018, s. 169) olarak tanımlamamıza olanak tanır. Stringberg'in alt sınıfa ait bir mekân olan mutfağı seçmesi ise Matmazel Julie' nin konumunu reddettiğine işaret eder. Strinberg, Matmazel Julie'nin önsözünde bunu şu şekilde ifade etmiştir (Strindberg, 1888/2012a, s. 7-8): 


\begin{abstract}
Ben, Matmazel Julie'nin trajik alınyazısının, birçok nedenlerin sonucu olduğunu düşünüyorum: Annenin kişiliği, babanın kızını yanlış yetiştirişi, kendi yaratılışı, nişanlısının güçsüz, yozlaşmış bir kafa üzerindeki etkisi. Ayrıca, doğrudan doğruya yaz dönümü gecesinin şenlik havası, babasının yoluğu, aybaşının tutması, hayvanlara düsšünlüğü, dansın coşkusu, alacakaranlığın büyüsü, çiçeklerin şehvet uyandırıcılığı bunlara eklenmelidir; son olarak da, iki kişinin bir odada yalnız kalmalarını hazırlayan olay; ayrıca, duyguları uyanmış bir adamın işini çabuk tutmak isteyişini de eklemek gerekir.
\end{abstract}

Tüm bu natüralist etkide ressentiment duygusunun oluşumunun zeminini hazırlayacak hem iç hem dış faktörleri de görebilmekteyiz. Oyunda Beauvoir'ın ifade ettiği şekilde kadını özerk bir özgürlükle içkinliğe mahkûm eden erkek egemen bakış açısı kadını köle konumuna yerleştirir. Aşkın konumundaki erkeğin ise hegemonik erkeklik ile sınıfsallaştııılarak kendinde varlıktan kendi için varlığa geçmesi engellenir. Bu durum Hegel'in köle-efendi diyalektiği ile anlamlı hale gelir. Kont hem sınıfsal olarak hem de ataerkinin meşruiyet dolayımında piramidin en üstünde bulunur. Kont, hem Nietzscheci hem de Hegelyen köle-efendi ilişkisi içinde soyludur ve efendi ahlakına sahiptir.

Kristin ise, -Beauvoir'ın ifade ettiği şekliyle- hem kendi sınıfını kabullenmesinden hem de toplumsal cinsiyet normlarını içselleştirmesinden dolayı köle-efendi diyalektiğinde köleliği kabullenmiş ve ahlaki normlara sıkı sıkıya bağlı kalmıştır. Sosyal Darwinist bir noktadan ele alındığında ulaşamayacağı üst konum, hayatta kalabilmek için Hegelyen bir bakış ile kendi yerini kabullenmesine yol açar. Kristin'in muhafazakâr kimliği, ölümden sonra iyi bir yaşamla ödüllendirileceği inancıyla ressentimenta dönüşmez. Dolayısıyla Nietzscheci anlamda soylu ahlakla bir problemi yoktur.

Scheler, Hıristiyan ahlakının, ardından bu ahlakın Fransız Devrimi ile yerini alan burjuva ahlakının ressentimentda kök saldığını söylemektedir (1912/2015, s. 81). Yani Scheler Hıristiyan ahlakının temelinde ressentimentın olmadığını ancak Hıristiyan ahlakının sevgi anlayışını kullanarak ressentiment yarattığını söylemektedir. Çünkü "zayıflık, korku, endişe ve kölece bir mizaç onun bu değerlere ulaşmasına engel olur" (Scheler, 1912/2015, s. 74). Bu bağlamda Kristin'in oyundaki konumunu ve ressemtiment oluşumundaki engelini şu şekilde özetleyebiliriz: "Böylesine bir onur ve ahlaklılık gerçekte de hazindir, çünkü köleliğin insanın yüreğinden gelen daha iyiye ve daha yukarıya ulaşma istediğini nasıl yok ettiğini gösterir. Kristin gibiler toplumsal gelişimin önündeki en büyük engeli, sınıflar arası çatışmanın çıkmazını temsil ederler" (Goldman, 1914/2013, s. 45).

Bu bağlamda oyunda Julie'nin de Jean'ın da hem sınıfsal olarak hem 
toplumsal cinsiyet uzantısı dolayımında (ataerkil normlar) birbirleri ile girdiği çatışmada Nietzscheci efendi-köle ahlakının aynı bedende bulunduğu izlenir. Julie'nin toplumsal cinsiyet, sosyal statü ve aşk ilişkisinden kaynaklı uğradığı tahakküm ile Jean'ın sınıfından kaynaklı egemenlik altında olması her iki karakteri de ressentiment kavramıyla okumaya elverişli kılar. Kristin ile nişanlı olmasına rağmen temel motivasyonu sınıf atlayabilmek olan Jean ile Julie arasında "aşk" ve/veya "arzu" ile oluşturulmuş otorite oyunu, Kont'un onların üzerindeki baskısının uzantısında açığa çıkar. Kont ve Kristin ise hem sınıfsal hem de toplumsal cinsiyet bağlamında ressentimentın oluştuğu özneler değil, ressentimenta kaynaklık eden nesne ve/veya aracı konumundadırlar. Bu bağlamda Julie'nin de Jean'ın da toplumsal cinsiyete bağlı olarak yaşadıkları ressentiment, dramatik yönelişlerinin farklı olmasından dolayı ayrı ayrı ele alınmıştır.

\section{Julie'nin Ressentimentı}

On yedinci yüzyılın başından itibaren burjuvazinin ortaya çıkışıyla birlikte burjuva toplumunun değer ve normlarına göre oluşturulan ahlaki paradigma Viktorya Dönemi'nin en belirgin unsurlarından biri olmuştur. Burjuva toplumunun egemen kimliğini oluşturan beyaz, Hıristiyan, orta sınıf erkeklere karşı tüm "ötekiler" bu normların uygulayıcısı olmak durumundadır (Oranlı, 2017, s. 339-340). Oyunun yazıldığı dönemin Süfrajet Hareketis'nin güçlü olduğu ve kadın-erkek eşitliğinin tartışıldığı yıllara tekabül etmesi Matmazel Julie karakterinin oluşumunda önemli bir etkendir. Süfrajet Hareketi ve dönemin toplumsal cinsiyete dair yaklaşımı oyunda Julie'nin annesi üzerinden yansıtılmaktadır. Julie oyunda annesinden şu şekilde bahsetmektedir:

JULIE: (...) Annem doğuştan asil değilmiş, halktan biriymiş. Zamanın popüler fikirlerini öğrenerek yetişmiş: eşitlik, kadınların özgürlüğü falan. Evliliğe kesinlikle karşıymıs. Bu yüzden, babam ona evlenme teklif edince onunla evlenmeyeceğini söylemiş. Nitekim evlenmemiş de. Ben dünyaya gelmişim. Herhalde annem istememiştir beni. Annem beni 'çocukların doğal hali' dediği şeye uygun yetiştirmek istedi. Erkek çocuklara öğretilen her şey bana da öğretiliyordu ki kadınların erkeklerdęn aşağı kalır yanı olmadığını kanıtlayayım. Erkek kıyafetleri giyiyor, at binmeyi öğreniyordum ama ineklerin yanına yaklaşmam yasaktı. Atı kaşağılamam, eğerlemem, sonra da binmem bekleniyordu. Hatta toprağı işlemeyi bile öğretiyorlardı. Malikânemizde erkeklere kadın işleri, kadınlara erkek işleri verilmişti (Strindberg, 1888/2012b, s. 37-38).

Kalıtım ve çevrenin etkisi Darwinist bir bakışla Julie'nin, annesinin kızı olduğu,

5 Süfrajet Hareketi, temelde kadınların erkeklerle eşit haklara sahip olmak ve oy kullanma haklarını kazanmak için düzenledikleri eylemlerdir. 
ona benzerliği üzerinden verilmektedir. Annesinin toplumsal cinsiyet normlarına karşı duruşu ve bir erkeğin boyunduruğu altına girmek istemese de yaptığı evlilikle savunduğu değerlerin tersi eylemlerde bulunması sonucu yaşadığı bunalım evi yakmasıyla sonuçlanmıştır. Aşığına elindeki tüm parayı daha önce veren anneden dolayı evin onarımı için gereken maddi destek ise aslında kendisine ait olan parayı borç olarak aldıkları Kont'a aittir. Julie'nin çocukluğu annesi ile babası arasındaki güç ilişkisine tanık olarak geçmiştir. Julie'nin annesine hiçbir erkeğin boyunduruğu altına girmemek için verdiği söz kalmıştır. Kalıımın ve çevrenin etkisi bu unsurlar doğrultusunda gelişmiştir (Tüfekçi, 2003, s. 63-64).

JEAN: Bizim hanım bazı konularda pek titizdir ama her konuda değil. Kontes de sağlığında tıpkı böyleydi. Evde kendini en rahat hissettiği yerler mutfakla ahırdı ama hayatta tek atın çektiği arabaya binmezdi. Giysilerinin manşetleri pislik içinde olurdu ama düğmelerinde mutlaka Kont'un arması bulunurdu. Matmazel Julie de tıpkı onun gibi (Strindberg, 1888/2012b, s. 5).

Julie'nin annesine benzerliği yalnızca toplumsal alanda değil, toplumsal cinsiyet hiyerarşisi için de geçerlidir. Nişanlısından annesine verdiği sözü tutup erkeğin boyunduruğuna girmemek için ayrımış olması bu duruma örnektir. Aynı zamanda erkek egemen normlara bir başkaldırı olarak Julie' nin ressentimentı çevre ve kalıtımın etkisiyle annesinden mirastır denilebilir.

JEAN: (...) Bekar bir hanımın (boğazını temizler) babasıyla akrabalarını ziyarete gitmektense burada bizim gibilerle kalmak istemesi de tuhaf, öyle değil mi?

KRISTIN: O delikanlıyla olanlardan sonra yüzlerine bakmaya utanıyordur herhalde.

JEAN: Olabilir. Ama ne olursa olsun, adam düzgün biriydi. $O$ iş nasıl bitti, biliyor musun Kristin? Ben her şeyi gördüm ama onlara fark ettirmedim.

KRISTIN: Ne? Gördün mü?

JEAN: Tabii ya... Bir akşam ahırda adamı kendi tabiriyle 'eğitiyordu'. Ne yapıyordu dersin? Adamı kırbacının üzerinden atlatıyordu, tıpkı köpek eğitir gibi. Iki kere atladı, ikisinde de kırbacı yedi. Üçüncüsünde kırbacı onun elinden aldı, paramparça etti. Sonra da çekip gitti"' (Strindberg, 1888/2012b, s. 2-3).

Bununla birlikte yazgısının annesiyle olan benzerliği de önemlidir. Zira Julie başta Jean'ın aşkına inanarak daha sonra da Jean ile birlikte olmanın utancıyla kaçabilmek için elindeki parayı alıp Jean'a vermeye hazırdır. Ancak diğer taraftan Julie babasının da kızıdır. Kont'un kızı olmasından kaynaklı verili statüsü toplumsal olarak Julie'yi, kadının ekonomik özgürlüğünün olmamasından kaynaklı statüsünü belirleyenin erkek olduğu görüşünden yola çıkarak ikincilleştirir (Donovan, 2015, s. 152). Julie, Kont'a karşı hissettiklerini şu şekilde ifade eder:

JULIE: Sevdim, hem de cok sevdim, ama ondan nefret de ettim herhalde. Ben farkına bile varmadan öyle oldu sanırım. Ama bana kendi cinsimden nefret etmeyi öğreten, beni yarı erkek yarı kadın olarak yetiştiren de oydu! 


\section{arts}

Bu olanlar kimin suçu? Annemin mie Babamın mı? Benim mi? Neden, benim bu hayatta kendime ait hiçbir şeyim yok ki! Babamdan almadığım tek bir düşüncem, annemden almadığım tek bir duygum yok (Strindberg, $1888 / 2012$ b, s. 60-61).

Julie'nin annesi ile babasının arasında kalması onun özgürlüğünün çevrenin etkisiyle şekillenmesine neden olur. Kont ile annesi arasında kalan Julie için kendini var etmek imkânsız hale gelir. Dolayısıyla Kont'tan kaynaklı olarak Julie'nin ekonomik özgürlüğü de yoktur. Nietzsche'nin belirttiği hem köle hem efendi ahlakının aynı bedende bulunabileceği söylemi, Julie'nin babası ile Jean arasındaki ilişkide görülmektedir.

JULIE: Otur o halde. Dur bir dakika! Önce bana içecek bir şey verebilir misiniz? JEAN: Buz kutusunda ne var, bilmiyorum. Korkarım sadece bira var.

JULIE: 'Sadece' mi? Ben sade ve basit şeylerden hoşlanııım, birayı şaraba tercih ederim (Strindberg, 1888/2012b, s. 12).

Julie'nin verili statüsünü kabul etmek istememesi ve alt sınıfa kurduğu ilişki ile Julie'nin babasından kaynaklı toplumla kurduğu ilişkide özgürlüğünün ol(a)mayışı onun mecburen kurduğu otoriteye meşruiyetle bağlanmasına yol açar. Babasının otoritesine karşı -ki bu bir erkeğin otoritesidir ve annesi tarafından kabul edilmemiştirKont'a karşı duyduğu ressentimentı meydana getirir. Çünkü kadın olarak otoritenin aşkın konumuna verili statüsüne rağmen yükselemez. Dolayısıyla köle konumunda hayatını üst otoriteye karşı korumak durumundadır.

Toplumsal normlar ise Julie'yi makro ölçekte çevrelemektedir. Jean ile ilgilenmesine rağmen yine de ipler Julie'nin elindedir. Statüsünü ve efendi konumunu korumaktadır.

JULIE: (...) Siz içmeyecek misiniz?

JEAN: Biraya pek düşkün değilimdir ama siz emrederseniz içerim tabii.

JULIE: Emir mi? Bence kibar bir bey, yanındaki hanıma eşlik etmeli.

JEAN: Evet, doğrusu budur. (bir şişe daha açar ve bir bardak alır)

JULIE: Şimdi şerefime kadeh kaldır. (Jean duraksar) Koca adamsın, utanacak değilsin herhalde?

JEAN: (sahte bir ciddiyetle yere diz çöker ve kadehini kaldıır): Hanımefendinin serefine.

JULIE: Bravo! Ayakkabılarımı da öpeceksiniz ki tam olsun. (Jean bir an duraksar, sonra Matmazel Julie'nin ayağını tutup dudaklarını hafifçe değdirir) Mükemmel! Siz oyuncu olmalıymıssınız.

JEAN: (ayağa kalkarak) Yeter artık Matmazel. Biri görebilir.

JULIE: Görseler ne olur?

JEAN: Milletin ağzına laf veririz, o olur! Daha biraz önce nasıl ileri geri konuşuyorlardı, bir duysanız... (Strindberg, 1888/2012b, s. 12-13).

Ancak Julie'nin Jean ile kurduğu aşk ilişkisi Kont ile benzer bir tahakküm ilişkisi yaşamasına yol açar. Aşk ilişkisinden doğan tahakküm, sınırların ve toplumsal normların Julie tarafından kaldırılmasına ancak yine de onun bir erkeğin 
egemenliğine sürüklenmesine neden olur. Julie'nin özgürleşme isteği, onun aşkın konuma geçebilme intimaliyle harmanlanır. Tüm baskılardan ve geçmişinden kaçabilme ihtimali Jean'ın hayallerine ortak olmasına böylece konumunu bırakarak kendini Jean'ın aşkına bırakmasına neden olur.

JEAN: Ben bir otel açacağım. Her şey birinci sınıf olacak, müşteriler dahil. JULIE: Otel mi?

JEAN: Evet! Hayatımızı yaşayacağız. Sıkılmaya, üzülmeye vakit olmayacak. (...) Yaşamak diye ben buna derim! JULIE: Iyyi güzel de ben ne olacağım? JEAN: Siz de evin hanımı, en güzel süsü olacaksınız. Sizin güzelliğinizle, sizin görgünüzle başarısı olmamı mümkün değil! Çok başarılı olacağız! Çalısma odanızda bir kraliçe gibi oturup tek bir düğmeye basarak köleleri işe koşacaksınız. Misafirler önce sizin tahtınızın önünde incelemeye tabi olacaklar. Servetlerini ürkekçe önünüze serecekler. (...) Hadi gidelim buradan! (cebinden bir tarife çıkarır) Hemen, bir sonraki trenle gidelim! (...) JULIE: Peki, tamam. Ama bana biraz cesaret vermen gerek, Jean. Beni sevdiğini söyle. Gel, beni kollarına al.

JEAN: (kararsız) İsterdim ama buna cesaret edemem. Tekrar bu evde olmaz. Süphesiz ki sizi seviyorum. Yoksa sizin bundan şüpheniz mi var?

JULIE: (mahçup, gerçekten kadınca hislerle) Siz mi! Bana sen diye hitap et.

Artık seninle aramızda bir sınır kalmadı. Bana sen de! (Strindberg, 1888/2012b,

s. 26-27).

Aşkın yarattığı tahakküm, sınıfsal farklııkları olan iki karakter için sürekli yer değiştirir ve ezen-ezilen dengesi tersine döner. Julie'nin Jean'a olan duygusal hisleri artık aralarındaki efendi-köle diyalektiğini tersine çevirmiştir. Jean seçkin ve kontrolü elinde tutan egemen güç, Julie ise egemenliğe boyun eğen kişi haline gelmiştir. Annesine verdiği sözü tutamayarak Jean karşısında köle konumuna düşen Julie, statüsüyle Beauvoir'ın kavramsallaştırmasıyla Jean karşııında aşkın konumda olmasına rağmen bu durumu korumayı başaramaz. Çünkü cinsel birliktelik yaşadığı alt sınıfın artık onu bir fetih gibi görmesi, Julie'nin konumunu koruyamamasıyla sonuçlanmıştır.

Cinselliğin tahakküm ilişkisine dayalı olması ve teslimiyetin tek taraflı yaşanması, kadınları erkekler tarafından fetih yapacakları nesneler olarak görmeleri, cinsel edimin mülkiyet, sahip olma ile ilişkili olmasından kaynaklanır (Bourdieu, 2014, s. 3334). Schopenhaur (1818/2019) Aşkın Metafiziği eserinde erkeğin doğası için kadını kandırmak pahasına gönlünü çalmasının türün bir gereği olduğunu zira kadının doğurganlığı ile erkeğin üreme arzusu ile ilgili olduğunu ve cinsel aşkın, âşık olunan kişiye karşı nefreti de besleyebileceğini söyler.

JEAN: Sana acıdığımı inkâr edemem. Artık söyleyebilirim. Soğanların arasında yatarken kafamı kaldırdığımda güllerin içinde seni gördüğümde, bütün erkek çocukların aklından nasıl müstehcen şeyler geçerse benim de aklımdan onlar geçti.

JULIE: Sonra da benim uğrumda ölmek mi istediniz!

JEAN: Yulafların içinde mi? Hikayeydi o.

JULIE: Hepsi yalan miydı yani? 
JEAN: (uykusu gelmeye başlar) Öyle sayılır. Gazetede öyle bir haber okumuştum sanırım. Bir baca temizleyicisi, kızın biri çocuğuna nafaka vermediği için kendisine dava açınca mürver çiçeği dolủ bir tahta sandığa girmiş.

JULIE: İşte masken düştü!

JEAN: Bir şey uydurmak zorundaydım, kadınlar böyle şatafatı laflara bayılılar (Strindberg, 1888/2012b, s. 32-33).

Julie'nin Jean'a söyledikleri aşkın tahakkümünden kaynaklanmaktadır. Bu durum, Jean'ın Matmazel Julie'yi aşkına inandırmak için söyledikleri ile Julie'nin birlikte kaçmak konusundaki tartışmasında verilmektedir. Jean üzerinde hem sınıfsal olarak hem de duygusal olarak üstün olduğunu düşünen Julie'nin, yaşanılan aşk ilişkisinde mağdur olması ve üstünlüğünü kaybetmesi Jean' a olan ressentimentın da kaynaklarından biridir. Zira Julie, efendi konumundan köle konumuna geçmiştir ve bir çıkış yolu da yoktur.

JULIE: Bu evde sizinle dost hayałı yaşayacağımı mı sanıyorsunuz? Millet de arkadan konuşup duracak, öyle mi! Bu olaydan sonra babamın yüzüne bakabilir miyim sanıyorsunuz? Hayır, götürün beni buradan. Böyle bir rezaleti kaldıramam. Allahım, ne yaptım ben? Allahım! Allahım!

(Matmazel Julie ağlamaya başlar.)

JEAN: Hah, başladlik. Ne yaptınız ki siz? Bir sürü başka kızın yaptığından daha beter bir şey yapmadınız.

JULIE: Artık benden tiksiniyorsunuz işte. (isterik bir şekilde bağırarak) Düşmüş bir kadın olacağım! Düşmüş bir kadın olacağım!

JEAN: Benim olduğum yere kadar düşün, ben sizi kaldıııım.

JULIE: Nasıl şeytani bir güç itti beni size? Güçlünün zayıf üzerindeki cazibesi miydi bu, yoksa ayağa kalkanların düşenler üzerindeki cazibesi mi? Yoksa aşk mıdı? Bu şey aşk mıydı? Siz aşk nedir, bilir misiniz? (Strindberg, 1888/2012b, s. 30)

Ancak Julie'nin kafesteki kuşunun Jean tarafından öldürülmesi Julie için sonun başlangıcıdır. Zira Julie de kafesteki kuşu gibi ölüme sürüklenen bir yazgının içindedir. Onu eyleme geçiren son nokta da budur.

JULIE: (...) Beni zayıf sanıyorsun, sırf rahmim hayat meyvesini vermek için senin tohumlarını arzuluyordu diye seni sevdiğimi sanıyorsun! Senin dölünün yüreğimin altında taşımak, onu kendi kanımla doyurmak, senin çocuklarını doğurup ismini almak istediğimi mi sanıyorsun? Sahi senin adın ne?? Bugüne dek soyadını duymadım, hatta belki yoktur bile. Hırsızın karısı, kapıcının karısı falan diye çağıracaklar herhalde beni. Boynunda benim tasmamla gezen köpek! Düğmelerinde benim armamı taşıyan uşak parçası! Bir de seni aşçımla paylaşıp kendi hizmetkârımı mı kıskanacağım? (Strindberg, 1888/2012b, s. 53).

Julie'nin tekrar efendi konuma geldiği bu örnek, ressentiment kavramını taşımasının yanında Zizek' in (2003) Kırılgan Mutlak kitabında belirttiği ötekinin mağdur olduğu sürece iyi olduğu, aktör mağdur gibi davranmadığında ise "kötü" ötekiye dönüştüğü söylemiyle de örtüşmektedir (s. 71). Julie aşk ilişkisinin tahakkümünden kurtulup sınıfına ait davrandığında efendi konumunu yineler. Ancak üstünlüğünü korumayı başaramaz. 
Julie tüm bu ikili ilişkilerin yanında toplumsal normlarla ve bakış açısıyla da ablukaya alınmıştır. Hem sınıfsal olarak kabul görmeyecek bir birliktelik yaşaması hem de verili statüsü oyunda, Julie ile Jean'ın kaçma planlarında görülmektedir. Jean kaçmak için Julie' nin para bulması gerektiğini söylediğinde Julie' nin bulamayacağını söylemesi ve akabinde geçen konuşmada Julie' nin dişil ressentimentın oluşmasına neden olan toplumsal ahlak yasalarının ağılığını görürüz. Julie'nin dişil ressentimentı yalnızca toplumsal normlarla alakalı değildir, oyuna göre annesinin mirası olarak da karşımıza çıkmaktadır. Kristin toplumu temsil etmektedir. Sınıfını kabullenmiş olmasına rağmen efendisinin toplumsal ahlak yasalarına karşı yaptığı davranışlara karşı susamaz duruma gelir.

KRISTIN: Söyle bakalım, beni bunun aşçısı mı yapacaktın sen?

JEAN: (sert) Hanımın hakkında konuşurken düzgün bir dil kullan, lütfen.

KRISTIN: Hanımım mı!

JEAN: Evet, hanımın.

KRISTIN: Vay vay vay, söyleyene bak hele!

JEAN: Biraz daha az konuşup biraz daha çok dinlesen iyi olacak. Matmazel

Julie senin hanımın. Ona saygısızlık etmene sebep olan şey her neyse, dön

bir kendine bak.

KRISTIN: Benim kendime saygım var.

JEAN: Ama başkalarına saygısızlık ediyorsun!

KRISTIN: Kendimi küçük düşüremem. Sen bugüne kadar Kont'un aşçısının

seyisle veya domuz çobanıyla kırıştırdığını nerede gördün? Söylesene!

(Strindberg, 1888/2012b, s. 57-58).

Julie'nin Jean ile olan ilişkisinin sonucu olarak toplumu temsil eden Krsitin, konumuna rağmen Julie karşısında efendi konumuna dönüşmeye başlar. Julie kendi konumunu koruyabilmek için Jean'ın onun üzerinde kurduğu tahakkümü işletmeye çalışarak başka bir şehirde otel açma isteğinden bahseder. Ancak Kristin, "iyi bir Hıristiyan" olarak, bunu kabul etmez çünkü köle konumundan çıkmak gibi bir amaç içinde değildir. Böylece Julie toplumsal alana sıkışmış bir kadın olarak dişil ressentimentı ortaya koyar.

Son tahlilde Jean ile yaşadığı ilişkinin annesi ile babasının yaşadığı ilişkiye olan benzerliği ve köle-efendi diyalektiği çerçevesinde bir güç savaşına dönüşmesi, toplumsal normların dayattığı baskı ve babasının otoritesi Julie'nin ressentimentını oluşturan üç önemli faktördür. Bununla birlikte çevre ve kalıtımın da etkisinin görüldüğü oyunda bir anlamda annesinin ressentimentı Julie'nin mirası olarak da değerlendirilebilir. Sosyal darwinizm açısından Julie'nin yıkımı kalıtımın da etkisiyle çevreye uyum sağlayamaması ve hem kadın hem öteki olarak güçsüz kalıp ezilmesinin bir sonucudur. Hegelyen bir biçimde eski nişanlısı ve Kristin ile olan ilişkisinde efendi konumunda olan Julie, Nietzsche'nin efendi ve köle ahlakının aynı bedende 
buluşabileceği görüşünden hareketle Jean ve Kont'a karşı köle konumundadır. Böylece Julie hem efendi ahlakını hem köle ahlakını aynı bedende buluşturur. Beauvoir'ın kadının içkinliğe mahkûm olduğu görüşüyle kendi varoluşuna duyduğu öfke Scheler'in "dişil ressentiment" kavramıyla örtüşür. Beauvoir'ın söylemindeki içkinlikten aşkınlığa, kendinde varlıktan kendi için varlığa geçmesi için ötekiliği reddetmesi Matmazel Julie'nin intiharıyla sonuçlanır ki bu durum hem varlık olmak isteyen Julie'nin eylemde bulunmasının nedeni hem de ressentimentı oluşturan yan duyguların sonucudur.

\section{Jean'ın Ressentimentı}

Jean, evin uşağıdır ve alt sınıfa mensuptur. Toplumsal cinsiyet hiyerarşisinde ise alt sınıfta olmasından dolayı hegemonik erkeğin (Kont) tahakkümü altında ezilmektedir. Diğer taraftan bu erkekliği yaşamaya çalışmakta ve eril tahakkümü Julie ve Kristin üzerinden gerçekleştirmektedir. Jean sınıfını kabullenmek istemez. Jean'ın Fransızca bilmesi, yemek zevkleri, tabağın ısıtılmasını istemesi, bira yerine şarap içmesi onun üst sınıf zevkleri olduğunu ve sınıfına ait davranmak istemediğini gösterir.

JEAN: (...) Yiyecek güzel bir şey var mı, Kristin?

KRISTIN: (tavadan tabağa bir şey alıp Jean'ın önüne koyar) Bir parça böbrek var, senin için ayırdım.

JEAN: (yemeği koklar) Nefis! iş̧te buna delice derim ben! (tabağa dokunur) Ama tabağı Isıtsan iyi olurdu.

KRISTIN: Sen de bir başladın mı Kont'tan beter oluyorsun.

(...)

(Jean yemeğini yer. Kristin dolaptan bir şişe bira çıkarır)

JEAN: Yaz gündönümü gecesinde biraz mı içęceğim! Sağ ol, kalsın! Ben daha iyisini bulurum. (bir çekmeceyi açar ve altın mühürlü bir kırmızı şarap şişesi çıkartır) Bak, altın mühürlü! Bana bir kadeh ver. Şarap kadehi olsun tabii, doğru düzgün içeyim şunu (Strindberg, 1888/2012b, s. 3-4).

Jean'ın sınıfını kabul etmek istememesi onun kendini geliştirmiş biri olmasına rağmen hapsolduğu sınıfın hiyerarşisine olan öfkesini de beraberinde getirir. Sınıf atlamak üzerine kurduğu hayaller Jean'ın yalnızca toplumsal konumunun değil, erkeklik konumunun da yükselmesini istediği anlamına gelir.

JEAN: (...) Başka bir ülkeye, cumhuriyet idaresinde bir yere bir gidelim, göreceksiniz üniformalı kapıcımın bile önünde eğilecekler. Birileri yine eğilecek ama bu ben olmayacağım, göreceksiniz! Ben bu hayat için yaratılmamışım. Benim kumaşım iyi, kişiliğim iyi. illk dalı bir tutabilsem tırmanacağım. Belki bugün uşağım ama seneye otel sahibi olacağım. On yıl içinde bir ömür yetecek kadar para biriktireceğim ve Romanya'ya gidip kendime bir unvan satın alacağım. Belki de, belki de diyorum, son günlerimi bir Kont olarak geçireceğim (Strindberg, 1888/2012b, s. 28).

Ancak sınıf atlayamayacak olması ve Kont'un hep üstünde olan gölgesi 
Jean'ın mütemadiyen korku içinde beklemesine neden olmaktadır. Kont'un zili çalmasıyla ceketini değiştirip cevap vermesi, uşaküniformasının ağırlığını hissetmesine neden olur. Kont'a karşı sorgusuz itaati Jean'a konumunu hatırlatır. Hegel'in köleefendi diyalektiğinde görüldüğü gibi Jean hayatta kalabilmek için efendisine karşı büyük bir saygı duymak zorundadır.

JEAN: (...) Bir de Kont var. Ömrümde onun gibi birini daha tanımadım, kimseye de o kadar saygı duymadım. İskemlede eldivenlerini bile görsem kendimi küçücük hissederim. Onun zilini duydum mu ürkek bir at gibi sıçrarım. Şimdi bile onun dimdik duran çizmelerini gördükçe sanki bir şeyler benim belimi büküyor (Strindberg, 1888/2012b, s. 27).

Kont'un yarattığı ve Jean'ın içselleştirdiği hegemonya nedeniyle Jean, Beauvoir'ın kavramsallaştırmasıyla her ne kadar toplumsal cinsiyet hiyerarşisinde aşkın bir varlık dahi olsa hegemonik erkeklik içinde içkin bir varlığa dönüşmektedir. Bu bağlamda Jean'ın Kont'a duyduğu korku, onun ressentimentının etkendir. Toplumsal normlarla ablukaya alınmış olması onun eylemini gerçekleştirememesinin de nedenidir. Matmazel Julie ile yaşadığı ilişkide de Kont'un varlığını ve toplumsal normların baskısını hisseder. Hiyerarşik olarak dans etmek için bile sınıfsal farklar gözetilmek zorundadır. Bu bağlamda sınıfını kabullenmek istemeyişi ve imrendiği ancak ulaşamadığı sınıfa karşı duyduğu varoluşsal haset Jean'ın ressentimentının temel noktasıdır.

JEAN: Matmazel Julie, saygısızlık etmek gibi olmasın ama aynı kavalyeyle üst üste iki defa dans etmeniz doğru olur mu? Hele ki insanlar her şeyi yanlış anlamaya bu kadar meraklıyken.

JULIE: (hiddetle) Neyi yanlış anlayacaklarmış? Ne diyor bu adam?

JEAN: (itaatkâr) Beni anlamak istemiyorsunuz, kendimi daha net ifade edeyim. Bu büyük şerefi bekleyen başkaları varken sizden aşağı tabakadan birini tercih etmeniz hoș olmaz.

JULIE: Tercih mi? BU adamin aklından neler geçiyor böyle! Diyecek söz bulamıyorum! Ben, bu evin hanımı olarak hizmetkârlarımın dansını şereflendiriyorum. Gerçekten dans etmek istediğime göre, dansı idare edebilecek birini bulmam lazım ki millet bana gülmesin.

JEAN: Hizmetinizdeyim, hanımefendi. Emirlerinizi bekliyorum" (Strindberg, $1888 / 2012$ b, s. 7).

Julie'ye karşı sınıfsal olarak köle olma durumu her ne kadar Kont'tan kaynaklı olsa da, Jean buna uymak zorundadır. Julie'nin verili statüsü Jean'ın etkin bir rol oynamasının önünde engeldir. Toplumsal olarak yapılan bu baskı da Jean'ı ressentimenta götüren diğer bir etkendir. Ancak Julie'nin kendi konumundan vazgeçmesiyle diyalektik tersine işlemeye başlayabilir.

JULIE: (...) (Jean'a elini uzatır) Hadi, gel benimle leylak topla.

JEAN: Hanımımla mı gidecegim?

JULIE: Evet! Benimle!

JEAN: Ama bu mümkün değil! Kesinlikle olmaz! 
JULIE: Neden olmaz diyorsunuz, anlamıyorum. Şey zannetmiyorsunuz herhalde...

JEAN: Ben zannetmiyorum ama millet zanneder.

JULIE: Ne zannedecekler? Gönlümü uşağa kaptırdığımı mı?

JEAN: Beni hadsiz sanmayın ama bunlar görülmedik şeyler değil. Hem bu insanların hiçbir şeye saygısı yok.

JULIE: Tam bir aristokratsını!

JEAN: Evet, öyleyimdir.

JULIE: Peki, ya ben mevkiimden inmeyi tercih edersem?" (Strindberg, $1888 / 2012$ b, s. 14).

Bunun yanında Julie ile kurduğu ilişkide baskın taraf olması, egemen erkek kültürünün bir uzantısı olarak sınıfına rağmen tahakkümünü meşrulaştırmasıyla sonuçlanır. Bunun en önemli yöntemlerinden birisi de aşktır. "Cinsel aşkın, bu aşkın duyulduğu varlığa karşı en şiddetli nefretin hissedilmesiyle de bağdaşabilir" (Schopenhaver, 1818/2019, s. 59). Jean'ın, Julie'yi elde etmeye çalışırken aşk ve arzu ile ona yaklaşması, Julie'ye karşı sınıfsal bir öfke beslemesi onu elde edebilmesindeki temel motivasyondur. Jean'ın Julie'yi elde etmek için anlattığı hikâyede bu türden bir ilişkiden bahsedilebilir.

JEAN: Malikânenin içine hiç girmemiştim. Kiliseden başka bir yer görmemiştim. Burası çok güzeldi. Ne yaparsam yapayım hep orası aklıma düşüyordu. O lüksün tadına bir defa olsun varma arzusu düştü içime günden güne. Enfin! İceri girdim, gördüm ve hayran kaldım. Sonra birinin geldiğini gördüm. Kibarlar için tek bir çıkış vardı fakat benim çıkabileceğim yol başkaydı. O yolu seçmekten başka çarem yoktu. Koştum, atlayıp ahududu çalılarının içine düş̧üm. Çilek tarhını geçip gül bahçesine vardım. Orada pembe bir elbise ve beyaz çoraplar gördüm. O sizdiniz! Yabani otların arasına, devedikenlerinin, pis kokan ıslak toprağın içine düştüm. Sizi güllerin arasında görünce dedim ki, 'Bir hırsız cennete gidip meleklerle yaşar ama bir rençperin oğlu bu dünyada parka gidip de Kont'un kızlyla oynayamaz' (Strindberg, 1888/2012b, s. 20).

Hem sınıfına ait bilgi vermesi hem de Julie'ye çocukluğundan beri âşık olduğunu söylemesi Freire'nin (1991) Ezilenlerin Pedagojisi'nde boyun eğdirmek için manipülasyon, fethetmek, ötekileştirmek gibi unsurların kullanıldığından bahsetmesiyle örtüşmektedir. Ezilenlerin yaşadığı tahakküm, söylem ile üretilir. Aşk bu noktada bir manipülasyon aracı olmakla beraber Jean'ın Julie üzerinde kurduğu tahakküm de söylem üzerinden gerçekleşmesiyle bir çeşit fetihtir.

JULIE: (daha önceki gibi) Yurt dışına gidip evlenmek ve boşanmaktan başka çıkış yolumuz var mı?

JEAN: Ya ben alt sınifa mensup biriyle evlenmeyi kabul etmezsem?

JULIE: Senden alt siniftan biriyle mi?..

JEAN: Evet, öyle... Benim soyum seninkilerden daha üstün. Ailemde kundakçılığa karışmış kimse yok.

JULIE: Nereden biliyorsun?

JEAN: Aksini kanıtlayamazsın, çünkü bizim polis kayıtları dışında bir aile şeceremiz yok. Ama ben, salonda duran bir kitapta senin aile şecereni gördüm. Ailenin kurucusu kimmiş, biliyor musun? Danimarka savaş eşnasında bir gece karısının kralla yatmasına izin veren bir değirmenci. Benim böyle atalarım yok. Hatta hiçbir atam yok ama ben birilerinin atası olabilirim (Strindberg, 1888/2012b, s. 42-43). 
Jean'ın Julie karşısında güçlü olabileceği tek alan toplumsal cinsiyettir. Jean da efendi konumunu erkekliği üzerinden gerçekleştirir.

Kadın için seref, negatif olarak tanımlanır ve yalnızca korunabilir ya da kaybedilebilir, zira kadının erdemi sırayla bekaret ve sadakatten ibarettir; oysa 'gerçek' bir erkek, zafer ve ayrımcllik elde etmek için kamusal alanda önüne çıkan fırsatları değerlendirmeye alma intiyacını hisseder (Bourdieu, 2014, s. 69).

Bu da Jean'ın Julie üzerindeki üstünlüğünü koruduğu başka bir noktadır. Julie'nin toplumsal sınıfını bir kenara koyarak Jean ile kurduğu ilişkide Jean, Julie üzerinde şeref, haysiyet gibi kavramlarla söylem üzerinden bir baskı kurar.
JULIE: Bir insan nasıl bu kadar pisliğe batar!
JEAN: Onu kendine sor.
JULIE: Adi uşak! Hizmetkâr parçası! Ben konuşurken ayağı kalk!
JEAN: Uşağın dostu! Hizmetkâr parçasının metresi! Kapa çeneni ve defol git buradan! Beni adilikle suçlamak sana mı kaldı? Benim gibiler asla senin bu gece adileştiğin kadar adileşmez. Bir hizmetçi kız, bir erkeğin peşinden senin koştuğun gibi koşar mı sanıyorsun? Benim sınıfıma mensup bir kızın kendini bir erkeğe böyle sunduğunu nerede gördün? Hayvanlar ve fahişeleri saymazsak ömrümde böyle şey görmedim ben.
JULIE: (yıkılmış) Haklısın, ez beni. Üzerime basıp geç. Ben bunu hak ettim! Rezil bir yaratığım ben. Ama yardım et bana! Bir yolu varsa bu durumdan kurtulmama yardım et! (Strindberg, 1888/2012b, s. 33-34).

Jean'ın hem sınıfsal hem de hegemonik erkeklik bağlamında Kont ile Julie arasında kurduğu ilişki Jean için de Nietzsche'nin köle-efendi ahlakının bir bedende bulunabileceğine örnektir. Kont'un dönüşüyle birlikte Jean'ın Julie üzerindeki tahakkümünü de yitirmeye başlaması ve sınıfını tekrar hatırlaması ile Kont'a duyduğu korku ve hasedin tekrarlanması -ki bu haset varoluşsaldır- ressentimentı yeniden hatırlatır.

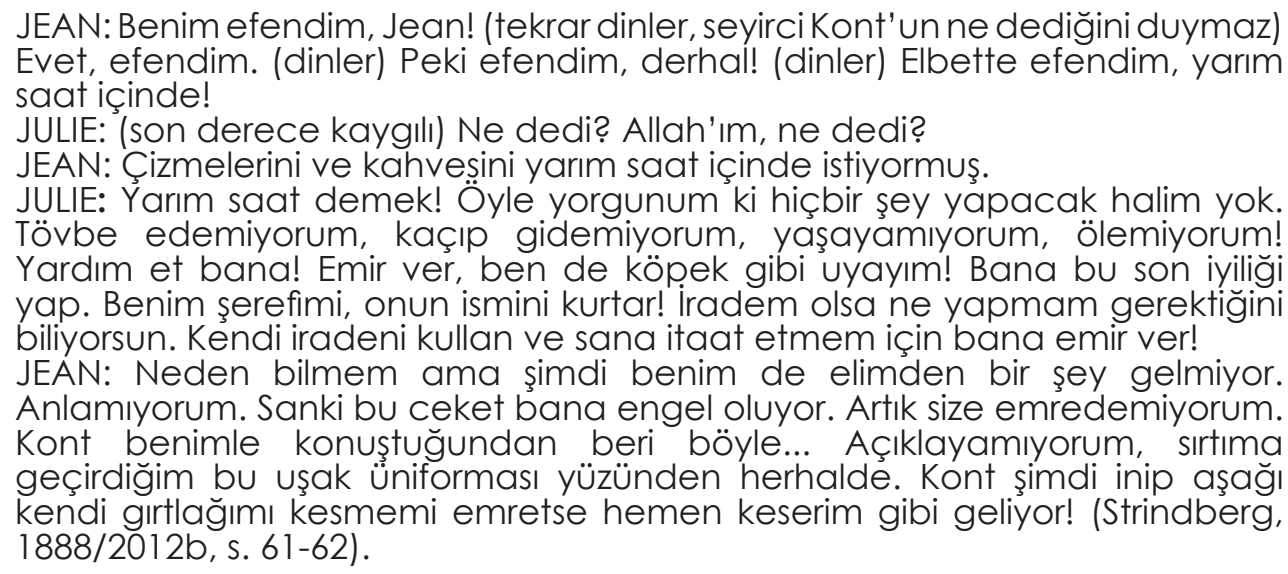

Oyunda Jean'ın Beauvoir'ın kavramsallaştırmasıyla aşkın konumda olması, yalnızca toplumsal cinsiyet hiyerarşisinin belirlediği konumdadır; Kont'a karşı içkin bir varlık olarak gördüğümüz Jean, Kristin ve Julie karşııında aşkın konuma geçer. 


\section{arts}

Hegelyen bir bakışla bu diyalektik ilişki Kont'a karşı köle konumunda olan Jean'ın kadınlar karşısında efendi konumunda olmasıyla sonuçlanır. Nietzscheci ahlak felsefesinde köle ile efendi ahlakının bir bedende olabileceği görüşü Jean'ın konumunu belirleyen önemli bir durumdur. Kadınlara karşı efendi ahlakını içinde barındıran Jean, hegemonik erkekliğin de bir sonucu olarak Kont'a karşı köle ahlakını barındıır. Bu bağlamda Jean'ın sınıfsal konumu ve toplumsal cinsiyet normları bir arada düşünüldüğünde Jean'ın ressentimentını oluşturan iki temel unsur olarak karşımıza çıkar. Sosyal Darwinist bir noktadan hayatta kalabilmek için güçlü olmaya çalışan Jean, çevreye uyum sağlamaya çalışır. Ancak yine çevre ve kalııımın etkisiyle bağlı olduğu sınıftan ayrılamaz. Bu bağlamda Jean'ın ressentimentı ulaşamayacağı sınıfın ve hegemonik erkekliğin sonucu olarak varoluşsaldır.

\section{SONUÇ}

On dokuzuncu yüzyıl Sanayi Devrimi, Modernleşme gibi gelişmelerle birlikte bilimsel olarak da gelişimin hızla yaşandığı bir yüzyıldır. Döneme damgasını vuran Evrim Teorisi, Sosyal Darwinizm ve edebiyatta Naturalist-Realist akımın öncülü konumundadır. Bu gelişmelerin yanı sıra Viktorya Dönemi Ahlak Yasaları'nın etkisi ve sınıflı toplum yapısının kadını sınırlandırıcı bakışı toplumsal cinsiyet normlarını önemli ölçüde şekillendirmiştir. Ayrıca bu dönemde Süfrajet Hareketi'nin yaşanması, toplumsal cinsiyet normlarına karşı bir başkaldırının olduğunu da göstermektedir.

Tüm bu gelişmeler çerçevesinde yazılan Matmazel Julie oyunu natüralizmin önemli eserlerinden biri olarak çevre ve katımın insanı şekillendirmedeki önemini sınıf ve cinsiyet çatışmasıyla yansıtır. Güç ilişkilerinin belirleyiciliği üzerine konumlandırılan oyun kişileri arasındaki çatışmanın bir çeşit efendi-köle diyalektiği olarak sürdüğü görülmektedir. Bu bağlamda çalışma Beauvoir'ın toplumsal cinsiyet yaklaşımı, Hegel'in efendi-köle diyalektiği ve Nietzsche'nin efendi-köle ahlakı ile ressentiment kavramını odağa almıştır.

Hegel'in efendi-köle diyalektiğinde kölenin hayatta kalmak için iktidara boyun eğdiği saptaması, Nietzsche'nin efendi-köle ahlakında bahsettiği bir beden içinde hem efendi hem köle ahlakının bulunabileceği görüşü birlikte değerlendirildiğinde oyun her iki karakter için de toplumsal cinsiyet bağlamında ressentiment yaşandığını göstermektedir. Beauvoir'ın kadını içkinliğe mahkûm, köle ruhuna hapsedilmiş kendinde varlık olarak görmesi, erkeğin ise aşkın bir varlık olarak kendi için varlık konumunda olması Julie ile Jean'ın ressentimentlarını oluşturan değişkenlerin farkılığı 
açısından önemlidir.

Julie verili statüsü nedeniyle üst sınıftan birisi olarak Kristin ve Jean'a karşı aşkın bir varlık olarak efendi konumundayken Kont'a karşı ve yaşadığı aşk ilişkisinden kaynaklı Jean'a karşı içkin bir varlık olarak köle konumuna da düşer. Jean ise alt sınıftan birisi olmasına nedeniyle içkin bir varlık olarak köle konumundayken toplumsal cinsiyet normlarının erkeklere tanıdığı avantajlar neticesinde aşkın bir varlık olarak efendi konumuna yükselir. Bu bağlamda aralarındaki tahakküm ilişkisi ve sürekli el değiştiren otorite, köle ile efendi ahlakının aynı bedende bulunmasına sebep olmaktadır. Julie' nin verili statüsü Jean'dan üstünken Jean'ın erkek egemen otoritesi Julie için üstünlük yaratır. Strinberg oyun kişileri arasındaki bu çatışmayı birbirleri Üzerine tam anlamıyla üstünlük kuramamasıyla yansıtır. Üst otoriteyi temsil eden Kont hem Hegelyen hem Nietzscheci bağlamda efendi konumunu korurken evin aşçısı Kristin 'iyi bir Hıristiyan' olarak sınıfını ve içkin bir varlık olarak köle konumunu kabul etmiştir. Dolayısıyla hem Kont hem Kristin'in ressentiment yaşamaları engellenir.

Sonuç olarak Kont'un hem sınıfsal hem hegamonik erkeklik üzerinden kurduğu tahakküm Jean ve Julie için haset, korku gibi unsurlardan kaynaklı olarak ressentimenta dönüşür. Annesi ile Kont arasındaki çatışmaya benzer biçimde Jean ile yaşadığı aşk ve arzu ilişkisi, sınıfı toplum yapısının yarattığı baskı ve hegemonya olarak Kont'un varlığı Julie'nin dişil ressentiment yaşamasıyla sonuçlanır. Bununla birlikte oyun Julie'nin annesinin baskın rolünü de bu bağlamda değerlendirmeye olanak tanıyarak Julie'nin yaşadığı ressentimentın yalnızca kendi deneyimleri neticesinde değil, annesinin mirası olarak da görülmesine olanak tanır. Jean ise hegemonik erkeklikten kaynaklı, yeteneklerine rağmen sınıf atlayamayacak olmasından dolayı varoluşsal ressentiment yaşamaktadır. Son tahlilde, toplumsal cinsiyet kalıp yargılarıyla çevrelenmiş oyun kişileri ekseninde toplumsal cinsiyet rolleri yeniden üretilirken toplumsal cinsiyete dair ayrımcılık ressentimet kavramıyla ortaya koyulur. Hem Julie hem de Jean'ın iktidarı tarafından konumlanması toplumsal cinsiyet rolleri ile doğrudan ilişkilidir. Zira on dokuzuncu yüzyılın bilimsel gelişmeleri ve natüralizmin etkisi toplumsal cinsiyet rolleriyle yeniden üretilmektedir. Bu bağlamda oyunun ataerkil söylemi pekiştirdiği anlaşılmaktadır.

\section{KAYNAKÇA}

Aydınalp, E. (2020). Varoluşçu Özgürlük Bağlamında Kadın: Simone de Beauvoir ve İkinci Cinsiyet. Litera, 30(2), 465-488. 
Beauvoir, S. D. (2019). Ikinci Cinsiyet: Yaşanmış Deneyim (Cilt 1-2, Çev. G. Savran). İstanbul: Koç Üniversitesi. (Özgün eser 1949 tarihlidir).

Berktay, F. (2015). Tarihin Cinsiyeti. İstanbul: Metis.

Bourdieu, P. (2014). Eril Tahakküm (Çev. B. Yılmaz). Ankara: Bağlam.

Bumin, T. (1987). Hegel: Bilinç Problemi, Köle-Efendi Diyalektiği, Praksis Felsefesi. İstanbul: Alan.

Connell, R. W. (2016). Toplumsal Cinsiyet ve iktidar (Çev. C. Soydemir). İstanbul: Ayrıntı.

Darwin, C. (1976). Türlerin Kökeni (Çev. Ö. Ünalan). Ankara: Onur. (Özgün eser 1859 tarihlidir).

Donovan, J. (2015). Feminist Teori (Çev. A. Bora, F. Sayılan \& M. A. Gevrek). İstanbul: İletişim.

Edinsel, K. (2014). Sosyolojik Düşünce ve Çözümleme: Etkenler, Oluşum Süreçleri ve Etkiler. 1.Cilt. İstanbul: Kabalcı.

Foucault, M. (2016). Özne ve iktidar (Çev. I. Ergüden \& O. Akınhay). İstanbul: Ayrıntı.

Freire, P. (1991). Ezilenlerin Pedagojisi (Çev. D. Hattatoğlu). İstanbul: Metis.

Goldman, E. (2013). Modern Tiyatronun Toplumsal Önemi (Çev. A. K. Yoviç). İstanbul: Agora. (Özgün eser 1914 tarihlidir).

Kongar, E. (2013). Toplumsal Değişme Kuramları ve Türkiye Gerçeği. İstanbul: Remzi.

Nietzsche, F. (2000). Ahlakın Soy Kütüğü Üstüne (Çev. A. İnam). Ankara: Gündoğan. (Özgün eser 1887 tarihlidir).

Oranlı, İ. (2017). Ondokuzuncu Yüzyıl Avrupası'nda Irkçlık ve Kadın Hareketi. Cogito, 58, 339-350.

Plumwood, V. (2017). Feminizm ve Doğaya Hükmetmek (Çev. B. Ertür). İstanbul: Metis.

Ressentiment. (1954). Larousse de Poche (s. 332). Paris: Librairie Larousse. 
Sancar, S. (2014). Türk Modernleşmesinin Cinsiyeti: Erkekler Devlet, Kadınlar Aile Kurar. İstanbul: İletişim.

Sartre, J. P. (2011). Varlık ve Hiçlik: Fenomenolojik Ontoloji Denemesi (Çev. G. Çankaya \& A. Öz). İstanbul: İthaki.

Scheler, M. (2015). Hınç (Çev. A. Yılmaz). İstanbul: Alfa. (Özgün eser 1912 tarihlidir).

Schopenhaver, A. (2019). Aşkın Metafiziği (Çev. S. Hilav). İstanbul: Yapı Kredi. (Özgün eser 1818 tarihlidir).

Soloman, R. (2016). Duygulara Sadakat: Hislerimiz, Bize Gerçekte Ne Anlatıyor? (Çev. F. Çoban). Ankara: Nika.

Strindberg, A. (2012a). August Strinberg Toplu Oyunları 1 (Çev. A. Çalışlar ve Z. Avcl). İstanbul: Mitos-Boyut. (Özgün eser 1888 tarihlidir).

Strindberg, A. (2012b). Matmazel Julie (Çev. R. E. Altınay). İstanbul: Agora. (Özgün eser 1888 tarihlidir).

Şener, S. (2017). Dünden Bugüne Tiyatro Düşüncesi. Ankara: Dost.

Tüfekçi, E. M. (2003). Oktay Rifat'ın Yağmur Sıkıntısı ve Auguste Strindberg'in Matmazel Julie Adı Oyunlarını Birlikte Okumak. Tiyatro Araştırmaları Dergisi, 16(16), 58-67. DOI: 10.1501/TAD_0000000020

Williams, R. (2018). Modern Trajedi (Çev. B. Özkul). İstanbul: İletişim.

Zizek, S. (2003). Kırılgan Mutlak (Çev. M. Öznur). İstanbul: Encore. 